\title{
Regulacja prawna oraz praktyka oceniania braku przeciwwskazań do wykonywania pracy - czesko-polskie porównanie i inspiracja
}

\section{Legal regulations and practice of the assessing the contraindications to work - Czech-Polish comparison and inspiration}

\author{
mgr Vojtěch Kadlubiec \\ Uniwersytet Masaryka w Brnie (Republika Czeska), Wydział Prawa, \\ Katedra Prawa Pracy i Ubezpieczeń Społecznych \\ ORCID: 0000-0002-2376-2804 \\ e-mail: kadlubiec.vojtech@gmail.com \\ dr Jan Horecký \\ Uniwersytet Masaryka w Brnie (Republika Czeska), Wydział Prawa, \\ Katedra Prawa Pracy i Ubezpieczeń Społecznych \\ ORCID: 0000-0001-8933-6624 \\ e-mail: jan.horecky@law.muni.cz

\section{dr Ariel Przybyłowicz} \\ Uniwersytet Wrocławski, Wydział Prawa, Administracji i Ekonomii, Zakład Prawa Pracy \\ ORCID: 0000-0003-4219-0984 \\ e-mail: ariel.przybylowicz2@uwr.edu.pl
}

\begin{abstract}
Streszczenie Autorzy porównują polskie i czeskie regulacje prawne dotyczące badań profilaktycznych pracowników, których celem jest stwierdzenie istnienia lub brak przeciwwskazań zdrowotnych do wykonywania pracy przez pracownika. Przedstawiają obowiązujące w obu państwach rozwiązania, zwracając uwagę na takie kwestie, jak podmioty uprawnione do orzekania o braku przeciwwskazań zdrowotnych do wykonywania pracy, rodzaje badań profilaktycznych oraz sytuacje, w których muszą zostać one przeprowadzone, charakter prawny orzeczenia lekarskiego i jego treść. Podejmują również próbę oceny obowiązujących przepisów, wskazując na problemy praktyczne oraz wady i zalety poszczególnych rozwiązań obowiązujących w obu krajach. Na tym tle formułują propozycje, w jakim kierunku powinny zmierzać zmiany legislacyjne w zakresie omawianej problematyki.

Słowa kluczowe: komparatystyka prawnicza, badania porównawcze, przeciwwskazania do wykonywania pracy, ocena przeciwwskazań do pracy, profilaktyczne badania pracowników, zdolność zdrowotna do pracy, orzeczenie lekarskie o zdolności do pracy.

Summary The presented article deals with Polish and Czech legal regulations of the preventive medical examinations of employees, which are aimed at assessing the absence of the medical contraindications to perform work. Attention is paid to the legal solutions in the subject matter in both countries, in relation, inter alia, to the bodies authorized to assess the medical contraindications to work, to the types of the preventive occupational medical examinations, to the cases of their compulsory pursuance and, last but not least, to the medical certificate on the health capacity to work and to its content. The article also includes the critical evaluation of the current legislation and points to the practical problems and advantages and disadvantages of the legal solutions in both countries. Based on the conclusions of the conducted comparative analysis, the authors also formulate some proposals for the legislative changes in the subject area.
\end{abstract}

Keywords: legal comparative studies, comparative studies, assesment of contraindications to work, preventive occuaptional medical examinations, health capacity to work, medical certificate on the health capacity to work.

JEL: K31

Str 13-22 


\section{Bibliografia}

Dawydzik, L. T. (2003). Ochrona zdrowia pracujących. Poradnik dla lekarzy i pracodawców. Warszawa: PZWL Wydawnictwo Lekarskie. Dörre-Kolasa, D. (2017). Komentarz do art. 229 kodeksu pracy. W: A. Sobczyk (red.), Kodeks pracy. Komentarz. SIP Legalis.

Jakubowski, J. Badania profilaktyczne pracowników. Aktualny stan prawny. Najczęstsze pytania i kontrowersje, https://lodz.pip.gov.pl/pl/f/v/93627/Badania\%20profilaktycz-ne\%20pracownikow.\%20Aktualny\%20stan\%20prawny. $\% 20$ Najczestsze\%20pytania\%20i\%20kontrowersje22.pdf (24.08.2018).

Janáková, A. (2011). Abecedabezpečnosti a ochrany zdravípřipráci. Olomouc: ANAG.

Jędrasik-Janowska, I. (2016). Pojęcia i konstrukcje prawne ubezpieczenia społecznego. Warszawa: Wolters Kluwer.

Kopias, J. A. (2015). Realia profilaktycznej opieki zdrowotnej nad pracownikami w Polsce. Medycyna Pracy, 66(6), http://medpr.imp.lodz.pl/pdf-60495-3781?ilename=Re- alia\%20profilaktycznej.pdf (24.08.2018).

Kowalska, K. Rzemek, M. (2018). Zmiany w badaniach pracowników. Rzeczpospolita (online), http://www.rp.pl/Ka- dry/303299907Zmiany-w-badaniach-pracownikow.html (29.03.2018).

Mitrus, L. (2018). Wypowiedzenie umowy o prace z przyczyn dotyczacych pracownika. Warszawa: C.H. Beck.

Parszuto, J. Zagożdżon, P. Jaremin, B. Ścisło, E. Korczak-Michałowska, A. (2008). Ocena jakości badań profilaktycznych pracowników wykonywanych przez lekarzy o różnych specjalizacjach i kwalifikacjach w województwie pomorskim w latach 2005-2008. Medycyna Pracy, 59(6), http://www.imp.lodz.pl/upload/oficyna/artykuly/pdf/full/2008/6_Parszuto.pdf (24.08.2018).

Pławucka, H. (2014). Ryzyko niezdolności do pracy dla celów rentowych — konstrukcja i treść. W: P. Bieniek i O. Rawski (red.), Niezdolność do pracy jako ryzyko w spolecznym ubezpieczeniu rentowym. Warszawa-Chorzów: Poligrafia ZUS.

Sikorska, A. (2015). Granice obowiązków stron stosunku pracy w zakresie badań profilaktycznych. Monitor Prawa Pracy, (2).

Šubrt, B. Tuček, M. (2017). Pracovnělékařské služby. Povinnosti zaměstnavatelů a lékařů po novelách právních predpisů. Olomouc: ANAG.

Tomšej, J. (2018). Pracovnělékařské služby. Praga: Wolters Kluwer.

Wągrowska-Koski, E. Rybacki, M. Śliwińska-Kowalska, M. Walusiak-Skorupa, J. Lewańska, M. Pas-Wyroślak, A. Klimecka-Muszyńska, D. (2011). Problemy orzecznicze $w$ badaniach profilaktycznych, http://www2.mz.gov.pl/wwwfiles/ma_struktura/docs/publikacja2_zd_24032011.pdf (24.08.2018).

Wittczak, T. (2018). Medycyna pracy. Profilaktyka i orzecznictwo. Warszawa: Difin. 